\title{
Study on Load-Carrying Capacity Zoning in Atmospheric Environment in Developing Countries - A Case Study of Can Tho City, Vietnam
}

\author{
Ho Minh Dung and Vu Hoang Ngoc Khue
}

\begin{abstract}
Air pollution in major cities of developing countries is a matter of great concern for managers, scientists, and people. In recent years, many studies have been done to simulate and forecast air quality for big cities in Vietnam as well as in the world with many air quality models have been used. However, studies using air quality models to evaluate the capacity of receiving air emission load in the atmospheric environment in local scale have not been carried out, especially in Vietnam. Therefore, the objective of this study is to assess load-carrying capacity in the atmospheric environment on a local scale for a smaller city at Mekong Delta, with a case study of Can Tho city, Vietnam. The FVM-TAPOM model system was established for the study area with the smallest grid resolution of $2 \mathrm{~km} \times 2 \mathrm{~km}$. The study results show that the atmospheric environment in Can Tho city still can receive more air emissions according to two seasons of the year (dry and rainy seasons) which are different depending on the seasonal wind direction. The central districts of Can Tho city (Ninh Kieu, Cai Rang, Binh Thuy, O Mon, and Thot Not) can only receive a smaller amount of emissions compared to the others (Vinh Thanh, Co Do, Thoi Lai, and Phong Dien). The amount of air emissions that can be received at the central districts is as follows: CO from 82,000 to 172,000 tons/year/district (696 2,142 tons/year $/ \mathrm{km}^{2}$ ); $\mathrm{SO}_{2}$ from 3,800 to 4,900 tons/year/district $\left(31\right.$ - 56 tons/year $\left./ \mathrm{km}^{2}\right)$; NOx from 217 to 328 tons/year/district $\left(1.8-3.4\right.$ tons $/$ year $\left./ \mathrm{km}^{2}\right)$. Similarly, the remaining districts can be received the emission is $164,000-653,000$ tons of CO/year/district $\left(1,308-2,555\right.$ tons/year $\left./ \mathrm{km}^{2}\right) ; 5,500-7,300$ tons of $\mathrm{SO}_{2} /$ year/district $\left(17-29\right.$ tons $/$ year $\left./ \mathrm{km}^{2}\right)$ and 31,000 44,000 tons of NOx/year/district (77 - 147 tons/year $/ \mathrm{km}^{2}$ ).
\end{abstract}

Index Terms-Air quality model, load-carrying capacity zoning, local scale, Can Tho city.

\section{INTRODUCTION}

Air pollution is one of the environmental issues that is one of the great concerns in big cities in developing countries around the world including Vietnam. According to the national environmental report in 2013, the air quality in Vietnam was worsening, especially in large urban areas, such as Hanoi and Ho Chi Minh city, causing severe problems to the public health as well as the environment. Therefore, in 2016, the Government issued Decision No. 985a/QD-TTg on

Manuscript received December 12, 2020; revised March 29, 2021. This research was supported by the Vietnam National University, Ho Chi Minh City (VNU-HCM) under grant number C2019-24-02.

Ho Minh Dung and Vu Hoang Ngoc Khue are with the Institute for Environment and Resources, Vietnam National University, Vietnam (e-mail h_minhdung@yahoo.com, vhnk1304@gmail.com).
June $1^{\text {st }}, 2016$ "Approving the national action plan on air quality management to 2020 , vision to 2025 " [1]. One of the tasks mentioned in this Decision is "Study of load-carrying capacity zoning in the atmospheric environment". The phrase "Load-carrying capacity zoning in the atmospheric environment" can be considered as that the maximum amount of air emissions the specific area can receive and guarantee that the ambient air pollution levels do not exceed the limited value regulated in the standard.

Up to now, only a few relevant studies have been carried out as follows: Daniel R. Mandelker et al. (1976), estimates the amount of emissions load that can be emitted into each county of several states in The United States. The study focuses on some air pollutants such as dust and $\mathrm{SO}_{2}$ from industrial activities. However, the study did not describe clearly the method of estimating the emission load for a county and identifying which areas would receive emission load [2]. Howard Fancy (2008), the first step is calculating the emission load from industrial activity. The next step is comparing the monitoring value or modeling results, if this concentration exceeds the standards, this area should require not to permit discharge, or companies that want to invest in must-have solutions to minimize emissions. On the contrary, the plant is allowed to invest in construction and operation [3]. Sarawut Thepanondh et al. (2014) calculated the maximum emission load of air pollutants for Dawai industrial zone, in Myanmar - India. The study used the AERMOD model to simulate the air quality. The research results show that the maximum emissions of $\mathrm{PM} 10, \mathrm{SO}_{2}$ and $\mathrm{CO}$ were $0.0025 ; 0.0031$ and $0.0075 \mathrm{~kg} / \mathrm{ha} /$ day, respectively [4]. Apiwat Thawonkaew et al. (2016) calculated the maximum emission load for Thailand's largest oil and gas industrial park - Maptaphut that used the AERMOD model to simulate air quality. Results indicated that the maximum $\mathrm{SO}_{2}$ emissions can be increased by about $130 \%$, and NOx should be reduced by at least $40 \%$ of the current levels, [5]. Smaranika Panda et al. (2017) calculated the maximum emissions potential in Manali industrial zone, India, using the AERMOD model to simulate air quality. The research results pointed out that the daily emissions of $\mathrm{SO}_{2}, \mathrm{NO}_{2}, \mathrm{PM} 10$ were 22.8 tons/day, 7.8 tons/day and 7.1 tons/day, respectively. Meanwhile, the maximum amount of air emission that can be released to the atmosphere for $\mathrm{SO}_{2}, \mathrm{NO}_{2}, \mathrm{PM} 10$ was 16.05 tons/day, 17.36 tons/day and 19.78 tons/day, respectively. Thus, $\mathrm{SO}_{2}$ emissions exceeded the safe load (6.7 tons/day), whereas PM10 and $\mathrm{NO}_{2}$ emissions were lower than the recommended amount [6]. Xu Da Hai et al. (2018) studied the atmospheric environment capacity in mainland China to calculate the ability to receive emissions in urban. This study 
did not use air quality models, but based on monitoring results, meteorological data, dry deposition rate, wet deposition rate, area of the study area, etc., to estimate the maximum emissions load for mainland China and the cities [7].

In Vietnam, up to now, there have been no studies on the zoning of emission load by using a modeling method. A few relevant studies such as Le Thi Thanh Thao et al. (2016) used the simple method that they compared the monitoring results with QCVN 05:2013/BTNMT (National technical regulation on ambient air quality in Vietnam, 2013) [8], if the monitoring concentration of air pollutants is lower than QCVN 05:2013/BTNMT, the area can receive more emissions, but the specific amount of pollutants were not given. This study only used the results of monitoring in some monitoring sites in Dong Nai province so this ability to receive is only at some points, not for the whole province [9]; Duong Hong Son (2003), used the AUM-V model to simulate air quality in the Hong River Delta. According to the simulation results, the author has proposed that the industrial development areas (with high emissions) should be located to the west of the urban areas, and need to observe the air quality index (AQI) in this area [10]; Nguyen Thi Thanh Tram (2015), used AQUIS air dispersion model to calculate, evaluate and zoning air pollution in Hanoi according to the AQI, thereby proposing several management solutions for Hanoi's air pollution mitigation [11]. Besides, based on the regulations QCVN 19:2009/BTNMT (National technical regulation on industrial emission of inorganic substances and dusts in Vietnam, 2009) [12] about the levels of industrial emissions discharge into the atmosphere, some provinces (such as Binh Dinh, Binh Phuoc, Ba Ria - Vung Tau, Dong Nai and Vinh Phuc, etc) has specific regulations on zoning emission discharge in their locality. However, these regulations not assessed the ability to receive emissions, or how much emissions load that area can assimilate or the area that is capable of receiving how much emission load but only gives $\mathrm{Kv}$ values for each area in the province according to QCVN 19:2009/BTNMT [13]-[17].

Modeling tools are widely used in air quality research and management. The models are mathematical tools that describe the processes of transport, diffusion and chemical reactions of air pollutants in the atmosphere. Currently, many different models in the world are able to simulate the distribution of air pollution, taking into account photochemical processes. In order to carry out this kind of studies that related to air pollution simulation, many dispersion model systems could be considered to take into account photochemical reactions such as TAPM-CTM, FVM-TAPOM, WRF-CMAQ, MM5-CHIMERE, etc.

\section{STUDY AREA}

The study area is Can Tho city, the economic center of the Mekong Delta, in the Southwest region of Vietnam (Fig. 1). The city has a total population of 1.25 million and covers an area of approximately $1,438 \mathrm{~km}^{2}$. The process of urbanization and the social-economic development of the city has increased environmental pollution, especially air pollution.

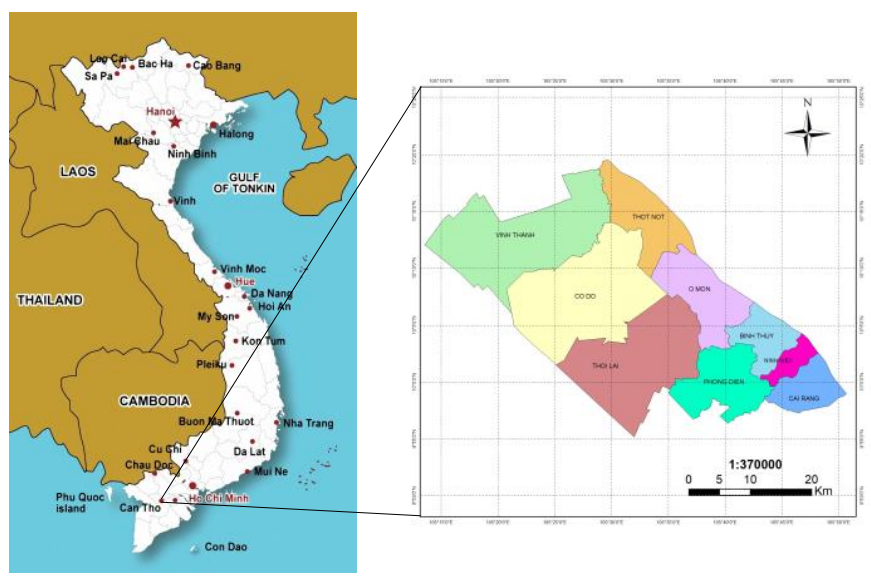

Fig. 1. Location of study area Can Tho city.

The considered air pollutants in this study include NOx, $\mathrm{SO}_{2}, \mathrm{CO}$, NMVOC (primary pollutants) and $\mathrm{O}_{3}$ (secondary pollutant).

\section{MATERIALS AND METHODS}

\section{A. Methodology}

As an overview, most of the studies are focused on the industrial areas and how much emissions that area can receive, usually applied for the small-scale area. Additionally, studies in Vietnam did not provide a detailed methodology and lack of using air dispersion models in the evaluation. Therefore, as a comprehensive approach, this study will take into account the air emissions data for a larger scale with many types of emission sources (traffic, industry, living, etc.), using an air quality model to develop air quality maps and compare the results with the standard, then adjust the emissions data to find out the limited value that the area can receive. As in large cities, the urban development plan should be integrated the economic and environmental plan to ensure the living conditions, otherwise, it may lead to many inadequacies in the social-economic problems. Thence, there is a need to develop planning and zoning air emission, which is considered as solutions for air environment management, contributing to environmental protection and sustainable development.

In addition, the distribution of air pollutants concentration depends on many factors including meteorological conditions and especially wind directions, therefore it should be taken into account for different periods of the year according to the seasons (prevailing wind direction). The methodology of the study on evaluating the emissions zoning in the atmospheric environment at a local scale (Fig. 2), including the following steps:

- Determining the study area: area dimension, resolution of the grid cell;

- Emission inventory:

1) Identification of sources and air pollutants

2) Selecting methods and calculate emission load

3) Display the emissions load in the study area.

- Air quality simulations:

1) Simulation meteorological conditions (in seasonal);

2) Simulation air quality (in seasonal);

- Editing the air pollution maps according to air pollutants 
by seasons, by regions;

- Developing the emission scenarios to calculate emission load capacity: Using methods of statistical and comparing simulation results and QCVN 05:2013/BTNMT (QCVN 05:2013) value to calculate the zoning of emission load received by the atmospheric environment; if $C_{m}>C_{q}\left(C_{m}\right.$ is the simulation value and $\mathrm{C}_{\mathrm{q}}$ is the permission value in
QCVN 05:2013), it means that area is not able to receive additional emission load; if $\mathrm{C}_{\mathrm{m}}<\mathrm{C}_{\mathrm{q}}$, it means that area is capable of receiving additional emission load, thereby calculate the atmospheric environment's ability to receive emission load of that area; then continue to simulate air quality until $\mathrm{C}_{\mathrm{m}}=\mathrm{C}_{\mathrm{q}}$. The concentration of air pollutants in this study is chosen to be 1-hour and 24-hour average.

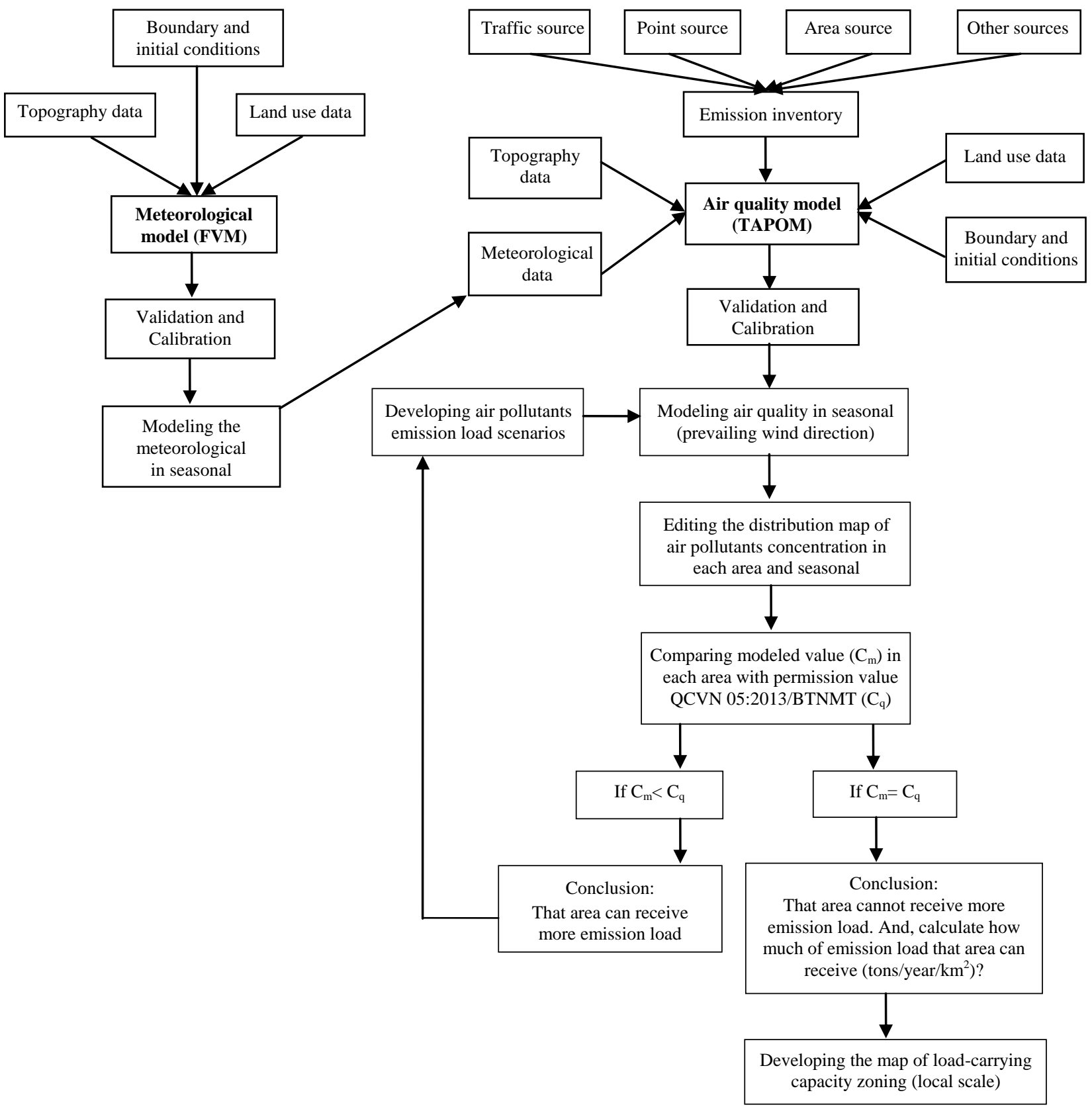

Fig. 2. Process of assessing load-carrying capacity zoning of the atmospheric environment (in local scale).

According to the simulation results of the current emission load levels, identify the periods and the areas that the pollution levels is higher and lower than the standard, as the following:

- Area (grid cell or district) that the air pollutants concentration exceeds QCVN 05:2013 value: simulate air quality with the emission reduction scenarios according to the different rates of concentration and re-simulation then, repeat the process until the concentration reduce to the allowable concentration levels and record the emission value.
- Area (grid cell or district) has air pollutants concentration is lower than QCVN 05:2013 value: simulate air quality with the emission increase scenarios based on the different rate of concentration.

If the new concentration of air pollutants is still lower than the standard, continue to increasing the emission load until the most recent concentration reaches the limited value, and at that time, calculate the corresponding emission load.

- Since $\mathrm{O}_{3}$ is the secondary pollutant that depends on the NOx and VOC rate, in the case of the concentration is higher than the standard, it is necessary to determine that 
this area is sensitive to NOx or VOC. Reducing NOx emissions and observe the trend of $\mathrm{O}_{3}$ levels, if the concentration reduces, it means that the levels of $\mathrm{O}_{3}$ at the area depend on NOx level conversely, it tends to depend on the VOC concentrations and have the reverse trend with the NOx concentration changes.

However, when simulation air quality, it should be paid attention that the dispersion and transportation of air pollutants from one area to another area depending on the meteorological conditions, for example, air pollution of area $\mathrm{A}$ is come from the emissions from the neighboring area $\mathrm{B}$, so that it needed to reduce the emission load of area $B$ to reduce the air pollutants concentration of area $\mathrm{A}$; and consider that when increasing the emission load in area $\mathrm{A}$, the concentration of air pollutants that area will be increased or not.

- Developing the zoning maps of the atmospheric environment with the potential receiving emissions according to seasonal (in prevailing wind direction) in the year.

\section{B. Material}

\section{1) Data and emission inventory}

\section{a) Emission data}

The general method for preparing emission inventory consists of three main steps: source identification, source classification, and emissions calculation. The selected time resolution is one hour. There are three main sources in the study area including line sources (traffic), point sources (industry), and area sources (living activities). Emission load calculations were carried out for the main air pollutants: NOx, $\mathrm{CO}, \mathrm{NMVOC}$, and $\mathrm{SO}_{2}$. And for spatial resolution, distribute the emissions according to grid cells adopted for air quality modeling ( $70 \mathrm{~km} \times 70 \mathrm{~km}$ with an area of $4 \mathrm{~km}^{2}$ per grid cell).

Emissions inventory for each source type is described as the following:

- Line source - Traffic source (includes on-road traffic and off-road traffic): Using EMISSENS model for on-road source [18] and using emission factors method for the off-road source;

- Point source - industrial activities: Calculating using the appropriate emission factors (combined with data collection survey);

- Area sources (includes household activities, restaurants, burning rice straw, gas station, etc.): Using the emission factor method (combined with data collection survey).

The calculation of emission load was carried out separately for each source and the authors had inherited from the research results of the project: "Establishing air pollution dispersion model and proposing solutions to protect the air environment for sustainable development in Can Tho city", chaired by Assoc. Prof. Dr. Ho Quoc Bang and finished in 2017 [19].

\section{b) Temporal and spatial emission distribution}

- Spatial distribution: emissions from sources in Can Tho city was displayed to grid cell by using GIS tools (Mapinfo 12.5). Using the grid size is $4 \mathrm{~km}^{2}(2 \mathrm{~km} \times 2 \mathrm{~km})$ with 35 points in each direction $\mathrm{x}$ and $\mathrm{y}$. The spatial distribution of the emission load depends on pollution sources. For traffic sources, the emission distribution is based on the total road length on each grid cell. For living sources, the emission distribution depended on the population density distribution. For industrial sources, the emission distribution according to the location of plants, the export processing zones/industrial zones, companies, etc.

- Temporal distribution: The emission distribution coefficient is calculated by the following formula:

$$
E_{h}=E_{a} * f_{m} * f_{w} * f_{d} / 8760
$$

In which, $E_{h}$ is the emission load per hour; $E_{a}$ is the annual emissions load; $f_{m}$ is the emission distribution coefficient per month; $f_{w}$ is the emission distribution coefficient per week; $f_{d}$ is the emission distribution coefficient per day; 8760 is the total number of hours in a year.

The emission distribution coefficients $\left(f_{m}, f_{w}\right.$ and $\left.f_{d}\right)$ are determined by different methods for each source. For traffic source, the emission distribution coefficient is the daily traffic load curve which observed in 24-hour on weekdays, and weekends. For industrial sources, the emission distribution coefficient is determined based on the results of air quality monitoring combined with production needs in months, weeks and hours. And for living source, the emission distribution coefficient is determined based on the results of air quality monitoring combined with interview data on the time of cooking of the people in months, weeks, and hours.

\section{2) Air quality model system}

\section{a) The model system}

In this study, the authors use the FVM-TAPOM model system for study in Can Tho city. This model system was developed and applied in many countries in Europe (such as Switzerland, Spain, France, Italy, etc.), in the South America region (such as Colombia, Mexico), and developing countries like Vietnam (Ho Chi Minh City, Can Tho city). This model system is well performed and reflects correctly the physical and chemicals conditions of the atmosphere.

TAPOM (Transport and Air Pollution Model, Martilli A. et al., 2003) was developed by LPAS - EPFL, simulates the metabolism of air pollutants in the atmosphere. It is a three-dimensional Eulerian model using terrain and girds with finite volume discretization. It includes modules for transport, gaseous and aerosols chemistry, dry deposition, and solar radiation. It includes the RACM lumped species mechanism. The four basic sets of input data are needed for TAPOM model such as: meteorological data, emission data, topography and land use data [20].

The FVM model (Finite Volume Model, Clappier A. et al., 1996) was developed by LPAS - EPFL, which is a 3-dimensional Eulerian model with finite volume discretization. Initial and boundary conditions for the model are taken from the global prediction model. In order to reflect exact the influence of urban surface on meteorological parameters in the boundary layer as well as on the diffusion of air pollution, the nesting-one-way technique is used in simulation processes [21].

\section{b) Set up model}


- Simulation area: Five different domains (from D1 to D5) are modeled by the FVM model (Fig. 3 \& Fig. 4). The dimension of each domain is $3000 \mathrm{~km} \times 3000 \mathrm{~km}(\mathrm{D} 1)$, $1500 \mathrm{~km} \times 1500 \mathrm{~km}(\mathrm{D} 2), 528 \mathrm{~km} \times 528 \mathrm{~km}(\mathrm{D} 3), 245 \mathrm{~km}$ $\times 245 \mathrm{~km}(\mathrm{D} 4)$ and $70 \mathrm{~km} \times 70 \mathrm{~km}(\mathrm{D} 5)$. Horizontal dimensions of the grid cells are $150 \mathrm{~km} \times 150 \mathrm{~km}, 75 \mathrm{~km}$ $\times 75 \mathrm{~km}, 16 \mathrm{~km} \times 16 \mathrm{~km}, 7 \mathrm{~km} \times 7 \mathrm{~km}$, and $2 \mathrm{~km} \times 2 \mathrm{~km}$, respectively in both directions $\mathrm{x}$ and $\mathrm{Y}$. By using the nesting technique to simulate for large grid cell to the smaller grid cell, so that the wind and temperature results from the domain D1 are used as the initial condition and boundary condition for domain D2, etc. In vertical, grid cells extended up to $11,000 \mathrm{~m}$ is divided into unequal layers and increase gradually. The thickness of the layer near the ground and the top layer is $20 \mathrm{~m}$ and $1,000 \mathrm{~m}$, respectively.

- Domains and resolution: In order to simulation of air quality in a small area requires the accuracy and resolution of input meteorological data. And to reach these requirements, the FVM model was run by nesting grids approach with 5 domains and the resolution of the inner grid is $2 \mathrm{~km} \times 2 \mathrm{~km}$. The size and resolution of selected areas to simulate meteorological conditions in the study area are as follows: Domain 1 (D1): $20 \times 20$ points, grid size $150 \mathrm{~km} \times 150 \mathrm{~km}$ which covers some Southeast Asian countries (Myanmar, Laos, Cambodia, Thailand, Vietnam, ...) and part of the East Sea; Domain 2 (D2): $20 \times 20$ points, grid size $75 \mathrm{~km} \times 75 \mathrm{~km}$ covering a part of South Vietnam, Cambodia, Thailand and part of the East Sea; Domain 3 (D3): $35 \times 35$ points, the size of the grid is $16 \mathrm{~km} \times 16 \mathrm{~km}$ covering the Southern provinces and part of the South Central region, part of the East Sea and parts of Cambodia; Domain 4 (D4): $38 \times 38$ points, grid size $7 \mathrm{~km} \times 7 \mathrm{~km}$ and only covers the Southwest provinces; Domain 5 (D5): $35 \times 35$ points, grid size $2 \mathrm{~km} \times 2 \mathrm{~km}$, covering the whole area of Can Tho city.

- Initial and boundary conditions: Initial and boundary conditions of this model are obtained from NCEP's global weather model (National Centers for Environmental Prediction) at http://www.cdc.noaa.gov. This data has a horizontal resolution of $2.5 \times 2.5$ longitude with 17 levels of pressure, at $0 \mathrm{Z}, 6 \mathrm{Z}, 12 \mathrm{Z}$ and $18 \mathrm{Z}$. This data is available from January 1, 1948 to now.

- Topography and land use data: The input data for the FVM model also includes terrain elevation, land use types, lands and water, soil type, percentage of vegetation and temperature of average annual soil layers. These data are taken at a resolution of $1 \mathrm{~km}$ from USGS (US Geological Survey) at http://www-tem.jrc.it, topographic data is available in http://edc.usgs.gov with $1 \mathrm{~km}$ resolution.

- Simulation period: Based on meteorological conditions, especially the prevailing wind direction in the study area and air quality monitoring data, we selected 2 periods in the year for simulation, including March and August in 2015, corresponding to two represented seasons, dry season (in March with northeast wind direction) and rainy season (in August with southwest wind direction).
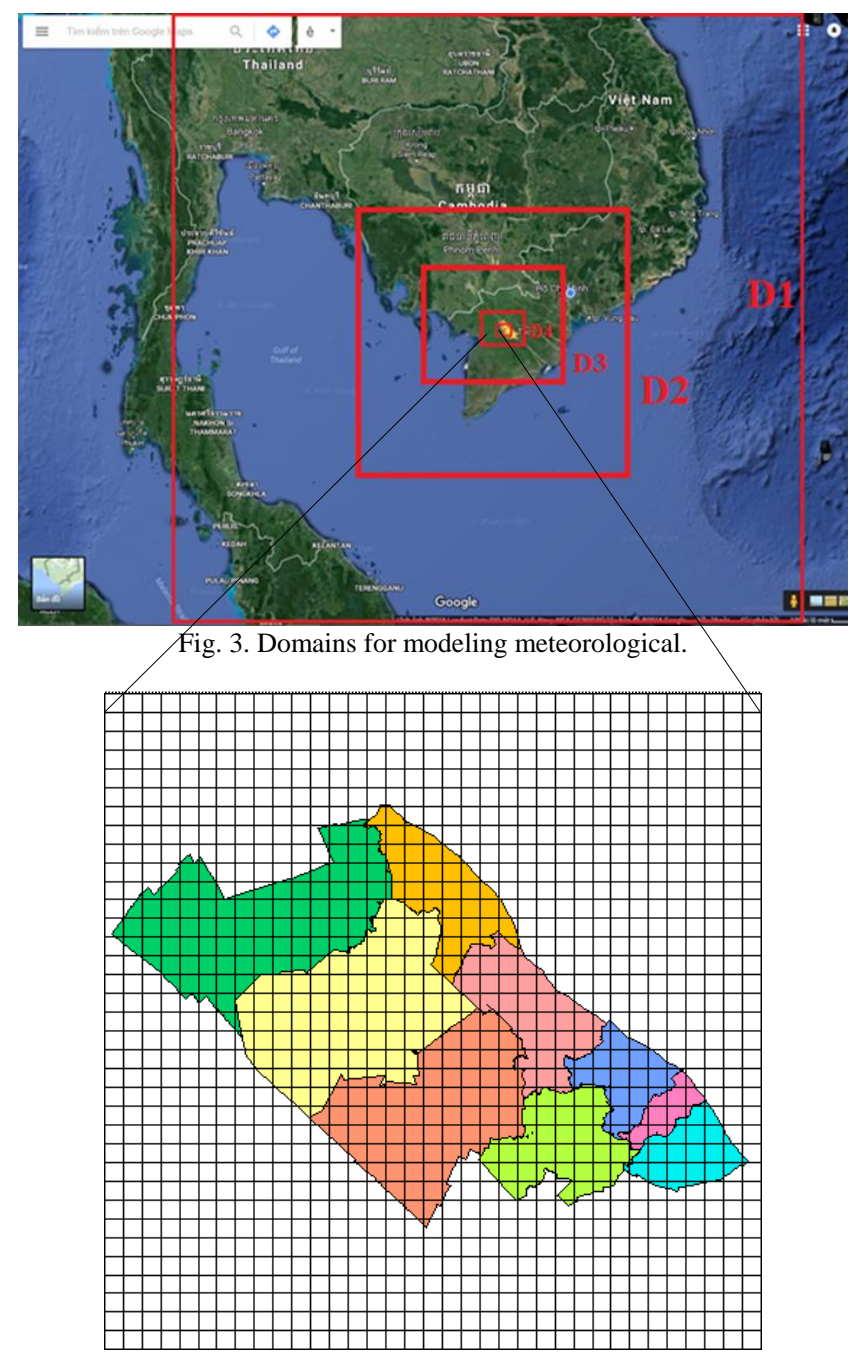

Fig. 4. Domain D5 for modeling air quality.

\section{c) Calibration and validation}

The quality of simulation results (meteorology and air quality) was assessed by measurement values at monitoring stations in domain D5 (smallest domain). Using the monitoring data in Cai Rang station $\left(10.0136^{\circ} \mathrm{N}, 105.784^{\circ} \mathrm{E}\right)$, located at Cai Rang ward, Ninh Kieu district, Can Tho city, for calibration and validation includes: meteorological parameters (temperature, wind direction and speed wind) and air quality parameters ( $\mathrm{NOx}, \mathrm{CO}, \mathrm{SO}_{2}$ and $\mathrm{O}_{3}$ ). Some common statistical parameters used to evaluate and compare results between observed values and simulated values are ME (mean error), MAE (mean absolute error), RMSE (root mean squared error), R (correlation coefficient), etc.

\section{RESUlts AND Discussion}

\section{A. Emission Data}

1) Total emissions: Average annual emissions of $\mathrm{NOx}$, $\mathrm{CO}, \mathrm{SO}_{2}$ and NMVOC are shown in Table I, in which NMVOC has the highest emission load (205,795 tons/year) and $\mathrm{SO}_{2}$ has the smallest emission load $(1,733$ tons/year). It is noted that traffic sources contributed the highest amount of $\mathrm{CO}$ emissions $(75.1 \%)$ and NMVOC $(61.9 \%)$, meanwhile the point sources contributed the highest load of $\mathrm{SO}_{2}(41.5 \%)$ and NOx (30.6\%); Area source also emitted a 
significant amounts of pollutants during the cooking activities (burning fossil fuel).

TABLE I. TOTAL AIR POLLUTANTS EMISSION LOAD OF EACH SOURCES IN CAN THO CITY IN 2015 (TONS/YEAR)

\begin{tabular}{|c|l|c|c|r|c|}
\hline No & Sources & NOx & \multicolumn{1}{c|}{$\mathrm{CO}$} & $\mathrm{SO}_{2}$ & NMVOC \\
\hline 1 & Traffic source & 4.983 & 315.131 & 855 & 127.351 \\
\hline 2 & Point source & 3.168 & 16.442 & 719 & 71.147 \\
\hline 3 & Area source & 2.201 & 88.283 & 159 & 7.297 \\
\hline & Total & 10,352 & 419,856 & 1,733 & 205,795 \\
\hline
\end{tabular}

2) Emission distribution: Steps for collect, statistics and calculate emissions have been carried out for the main sources of traffic, industry and domestic activities, then emissions from the sources are spatial distributed on digital maps showing the location and emission value of each area. The maps demonstrated that NOx was concentrating along with the road network and in Ninh Kieu district, a part of Cai Rang and Binh Thuy district with the highest emission load of 242 tons/year $/ 4 \mathrm{~km}^{2}$. Emissions of CO mainly came from traffic source (75.1\%) and in particular came from motorbikes, distributed in Ninh Kieu district with the emissions rate at 15,452 tons/year $/ 4 \mathrm{~km}^{2}$, while emissions of $\mathrm{SO}_{2}$ were concentrated at Ninh Kieu district with 36.8 tons $/$ year $/ 4 \mathrm{~km}^{2}$, mainly generated by the traffic sources $(49.3 \%)$ and industry sources $(41.5 \%)$; NMVOC is mainly generated by traffic source $(61.9 \%)$ with the distribution according to the traffic density, and the locations of textile and garment factories in Thot Not and $\mathrm{O}$ Mon industrial zone with emission load up to 60,000 tons $/$ year $/ 4 \mathrm{~km}^{2}$.

\section{B. Simulation Air Quality in Current Level}

1) Calibration and validation results
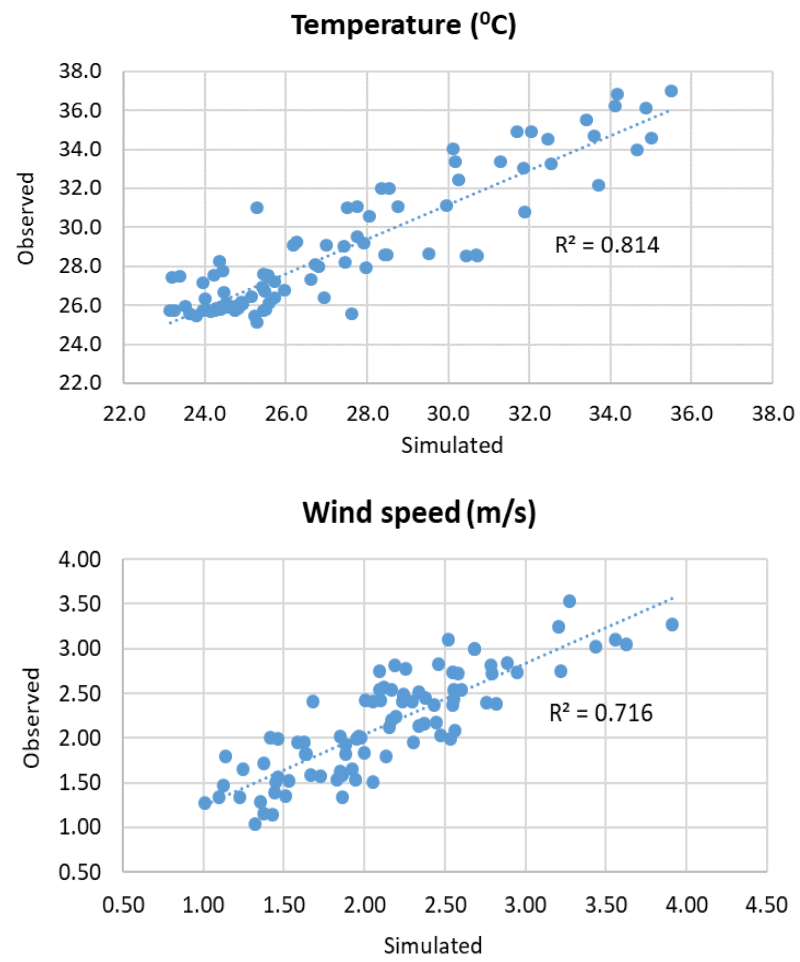

Fig. 5. The correlation between simulated and observed of temperature and wind speed value (in March, 2015).
The results of calibration and validation of FVM meteorological model and TAPOM air quality model in domain D5, the results showed that: For temperature, $\mathrm{R}^{2}=$ 0.814; $\mathrm{ME}=-2.73 ; \mathrm{MAE}=3.32 ; \mathrm{RMSE}=2.09 ;$ For wind speed, $\mathrm{R}^{2}=0.716 ; \mathrm{ME}=-0.03 ; \mathrm{MAE}=0.51 ; \mathrm{RMSE}=0.33$; For $\mathrm{CO}$ concentration, the correlation coefficient $\mathrm{R}^{2}=0.748$; For $\mathrm{SO}_{2}$ levels, the correlation coefficient $\mathrm{R}^{2}=0.816$. The calibration results show that the simulation values are quite accurate compared to the monitoring results.
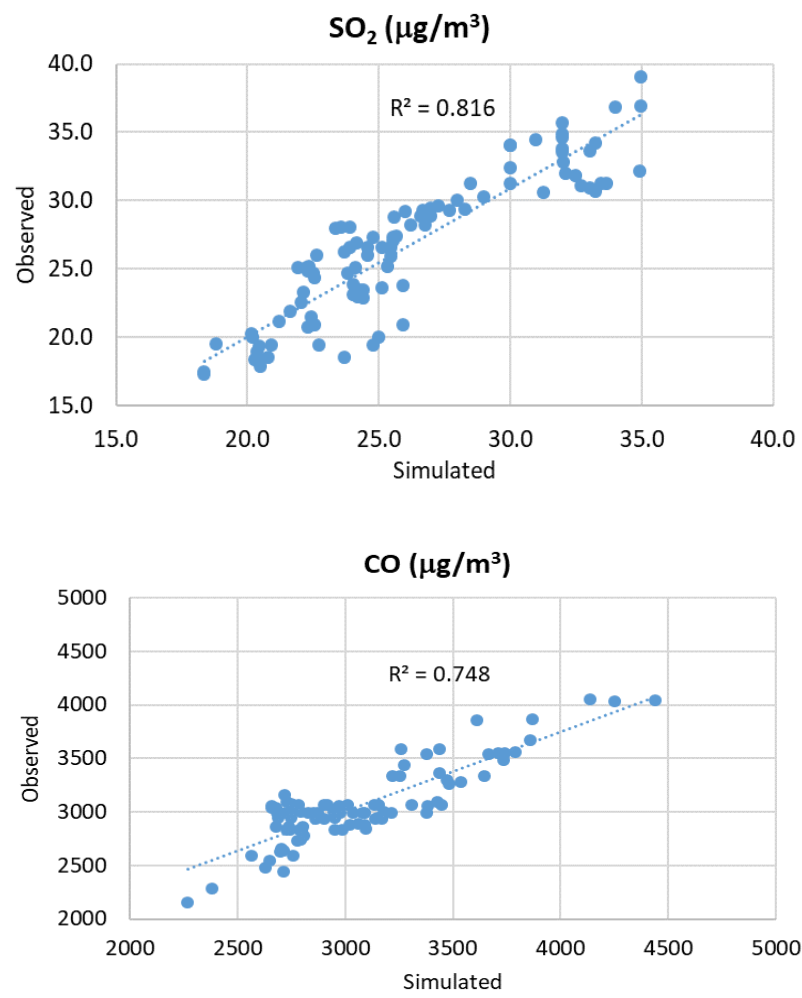

Fig. 6. The correlation between simulated and observed of $\mathrm{SO}_{2}$ and $\mathrm{CO}$ value (in March, 2015)

\section{2) Modeling results}

Simulation results based on the current emission level (summarized in Table II) shows that: the maximum 1-hour and the 24-hour average concentration of air pollutants $\left(\mathrm{SO}_{2}\right.$, NOx, CO) in both two seasons (dry and rainy seasons) were lower than the limited value of QCVN 05:2013/BTNMT (QCVN 05:2013). Similarly, the maximum 1-hour average and 24-hour average concentration of ozone during the dry season and rainy season were also lower than QCVN 05: 2013. Depending on the prevailing wind direction of the two seasons in the year, the distribution of air pollutant concentrations is varying, as follows: In the dry season, the prevailing wind blew toward the northwest direction, therefore the highest 1-hour concentration was at Binh Thuy district with the levels of $\mathrm{CO}, \mathrm{SO}_{2}$ and $\mathrm{NOx}$ recorded at 8 am on March 1, 2015 were $10,120 \mu \mathrm{g} / \mathrm{m}^{3} ; 25.6 \mu \mathrm{g} / \mathrm{m}^{3}$ and 131.9 $\mu \mathrm{g} / \mathrm{m}^{3}$, respectively. Similarly, during the rainy season, the prevailing wind direction simulated is toward the Northeast and the highest 1-hour maximum value was located in Ninh Kieu district (at 8 am on August 20, 2015) were $6,812 \mu \mathrm{g} / \mathrm{m}^{3}$ $\mathrm{CO} ; 18.3 \mu \mathrm{g} / \mathrm{m}^{3} \mathrm{SO}_{2}$ and $137.1 \mu \mathrm{g} / \mathrm{m}^{3}$ NOx, respectively. 
Mar 01/2015, 8:00, Co, ppb

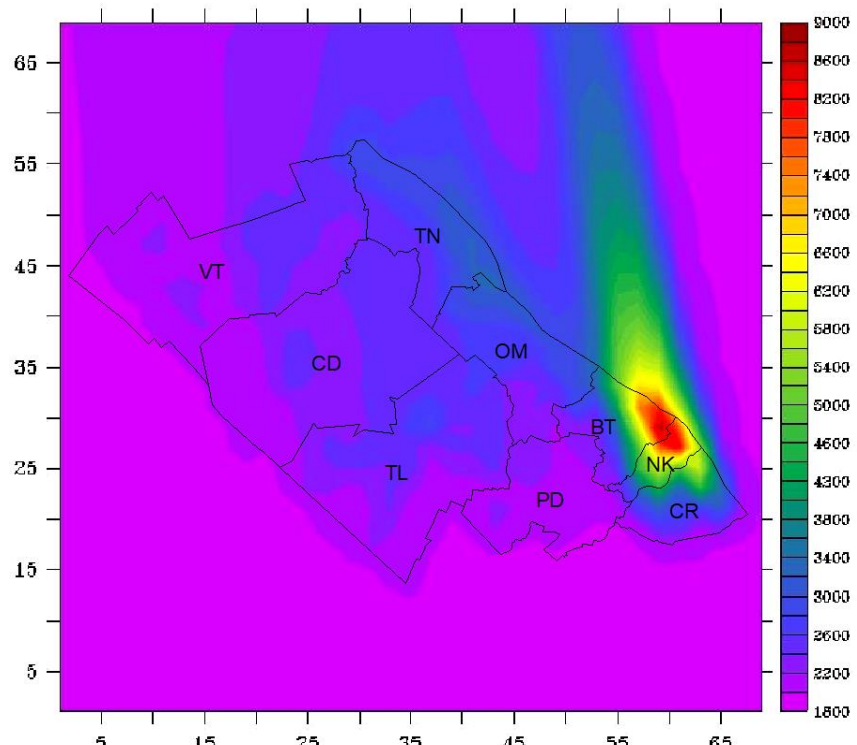

Mar 01/2015, 8:00, S02, ppb

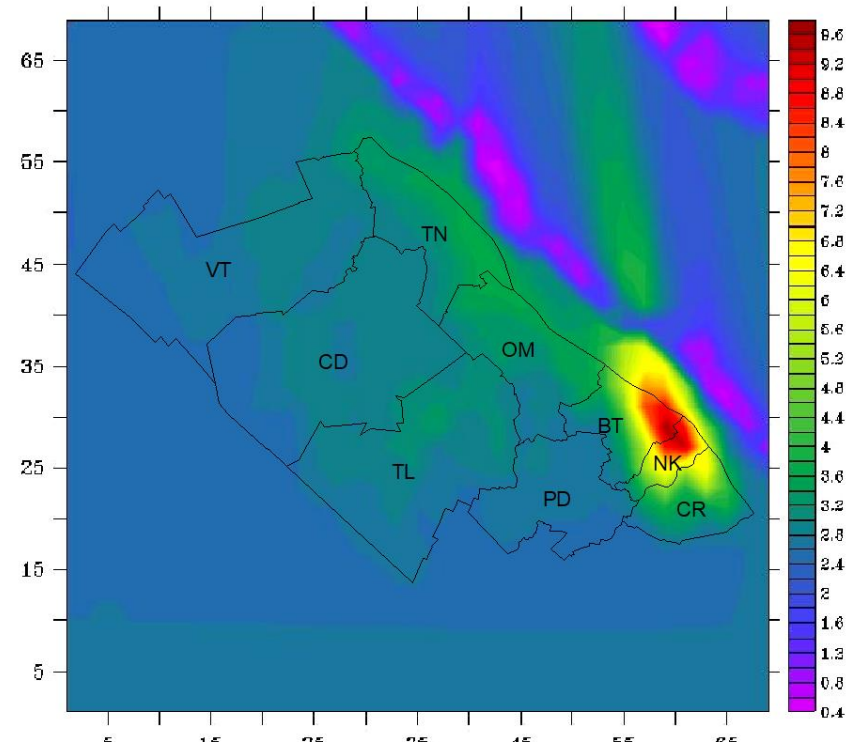

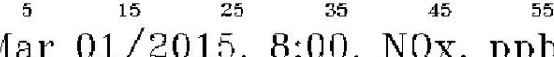

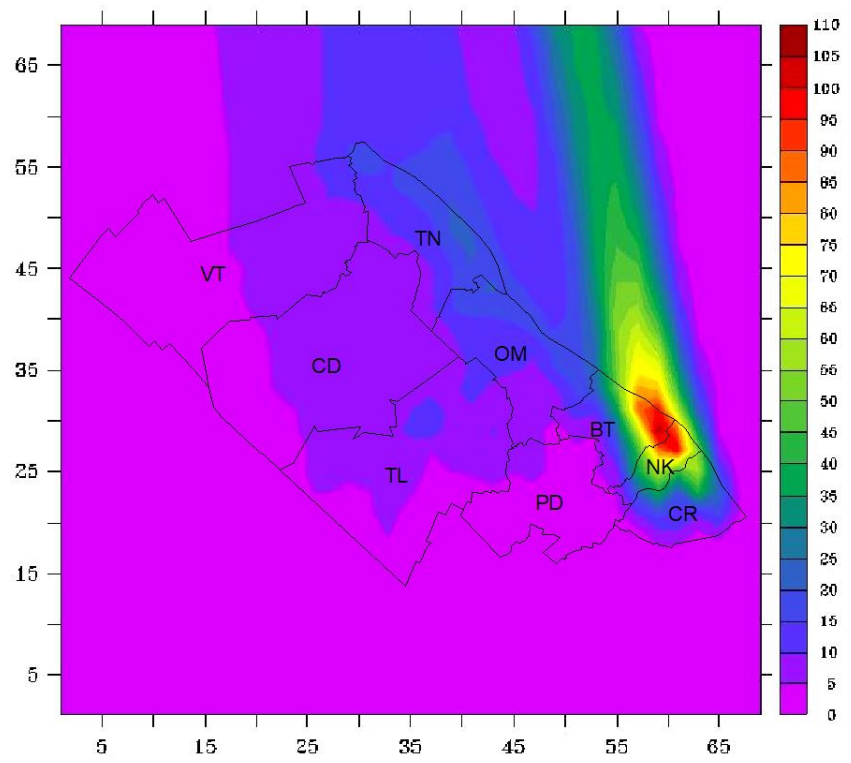

Mar 01/2015, 14:00, 03, ppb

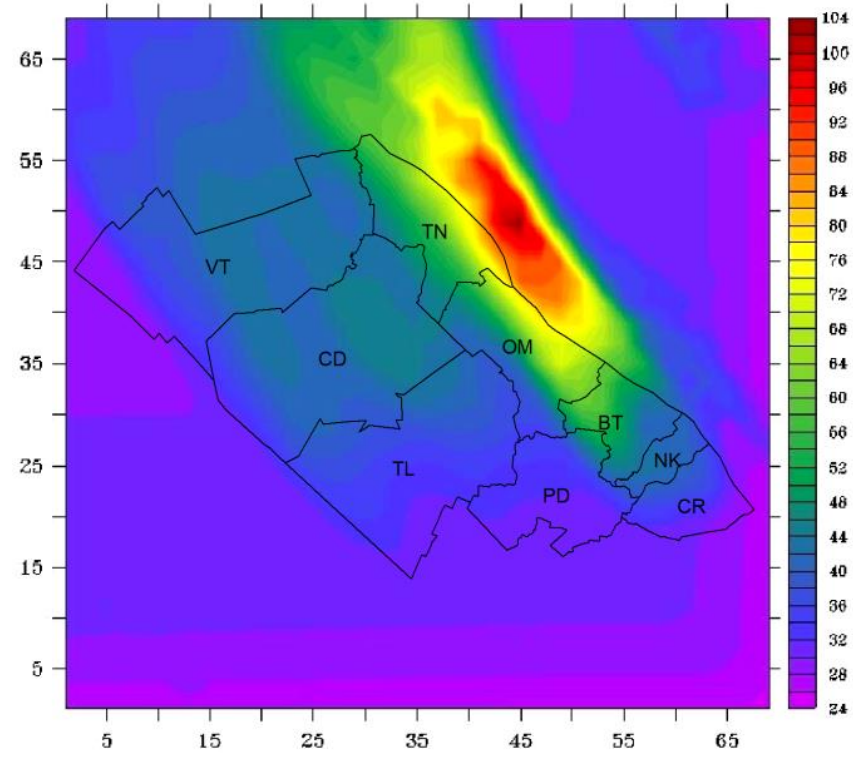

Fig. 7. The maximum 1-hour average of air pollutants concentration (CO, $\mathrm{SO}_{2}, \mathrm{NOx}, \mathrm{O}_{3}$ ) in dry season (in current emission level).

Aug 20/2015, 8:00, C0, ppb

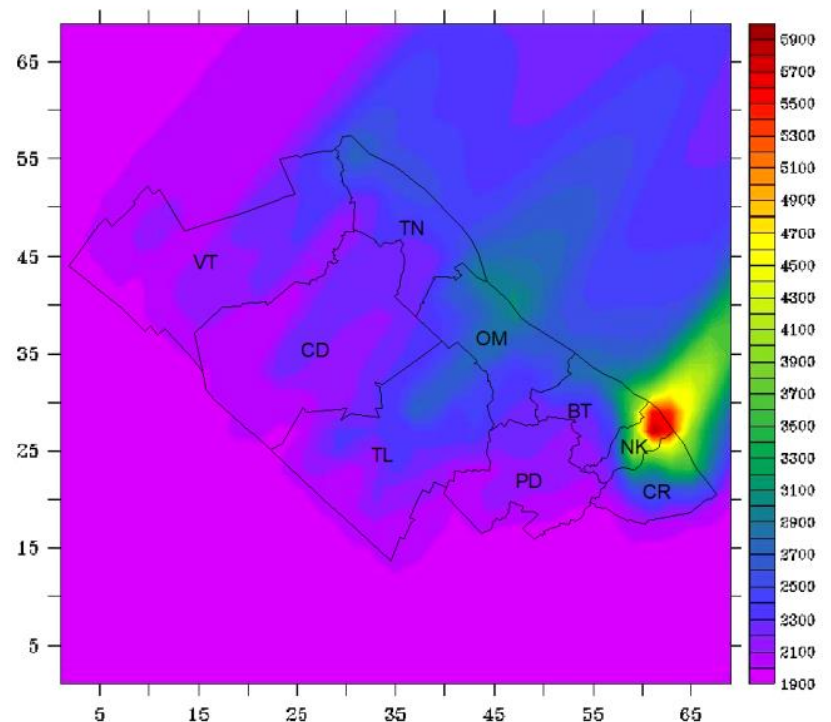

Aug 20/2015, 8:00, S02, ppb

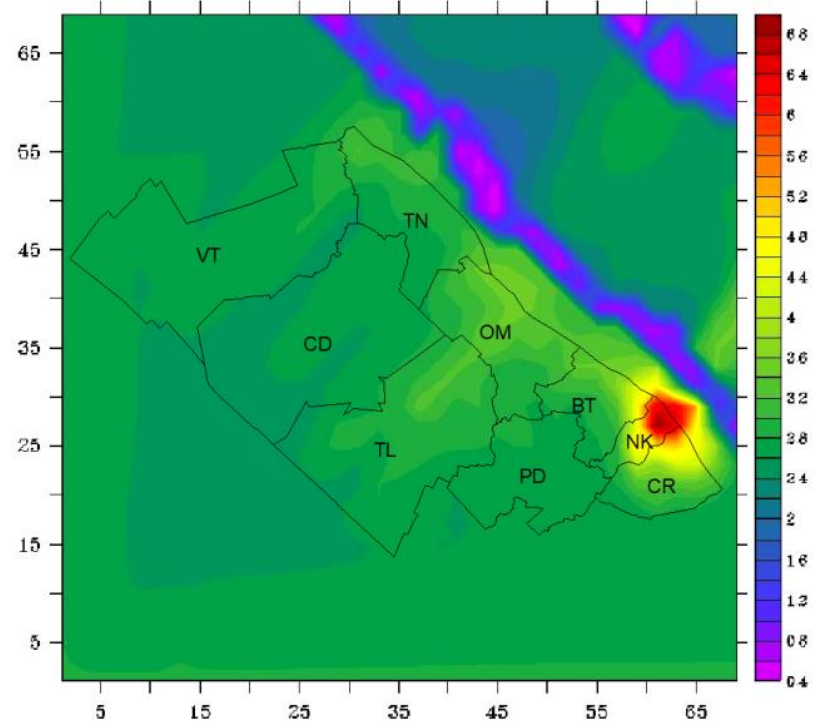


Aug 20/2015, 8:00, NOx, ppb

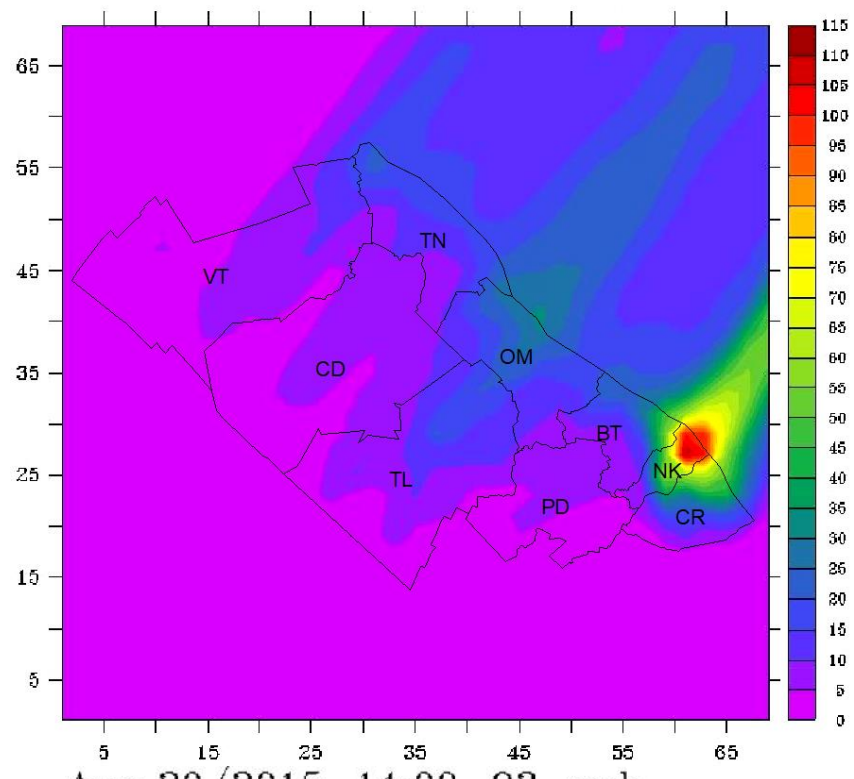

Aug 20/2015, 14:00, 03, ppb

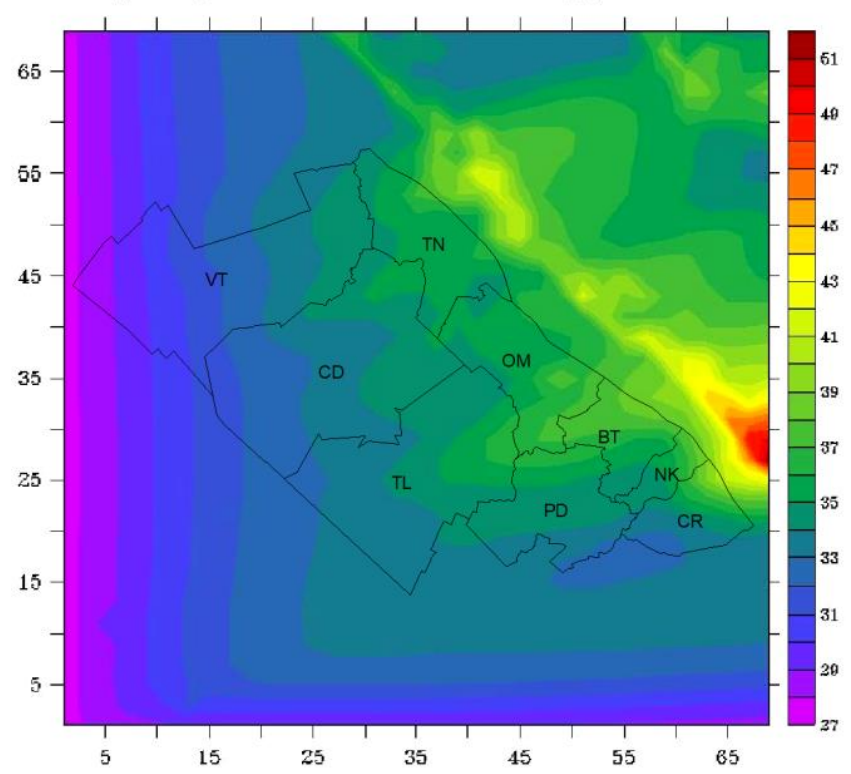

Fig. 8. The maximum 1-hour average of air pollutants concentration (CO, $\mathrm{SO}_{2}, \mathrm{NOx}, \mathrm{O}_{3}$ ) in rainy season (in current emission level).

For $\mathrm{O}_{3}$, the highest 1-hour concentration $\left(101.0 \mu \mathrm{g} / \mathrm{m}^{3}\right.$, at 2 pm on August 20,2015) was recorded outside the area of Can Tho city (located to the east of Ninh Kieu district) and lower than the standard. Similarly, the 24-hour average concentration $\mathrm{O}_{3}$ did not exceed the standard throughout 2 seasons. The peak concentration normally distributed around the city center (Ninh Kieu), while the other areas witnessed lower levels of pollution.

Generally, according to the simulation results, the city has the potential in receiving more air emissions.

\section{Emission Scenarios and Calculating Capacity of Emission Load}

The simulation results based on the current situation shows that the air pollutants levels were lower than the standard, which means that the atmospheric environment in Can Tho city had capable to receive more air emissions. And in order to calculate the amount of emission that the city can receive, the study will develop emission scenarios, adjust the air emission sources, as describes:
TABLE II: RESULTS OF AIR QUALITY SIMULATION WITH CURRENT LEVEL

\begin{tabular}{|c|c|c|c|c|c|}
\hline \multirow[t]{3}{*}{ Air pollutant } & \multicolumn{5}{|c|}{ 1-hour average concentration $\left(\mu \mathrm{g} / \mathrm{m}^{3}\right)$} \\
\hline & \multirow{2}{*}{$\begin{array}{c}\text { QCVN } \\
05: 2013 / \\
\text { BTNMT }\end{array}$} & \multicolumn{4}{|c|}{ Simulation value } \\
\hline & & $\begin{array}{c}\text { Dry } \\
\text { season } \\
(\max .)\end{array}$ & $\begin{array}{c}\text { Dry } \\
\text { season } \\
\text { (min.) }\end{array}$ & $\begin{array}{l}\text { Rainy } \\
\text { season } \\
\text { (max.) }\end{array}$ & $\begin{array}{l}\text { Rainy } \\
\text { season } \\
\text { (min.) }\end{array}$ \\
\hline 1. $\mathrm{SO}_{2}$ & 350 & 25.6 & 7.3 & 18.3 & 6.8 \\
\hline 2. NOx & 200 & 131.9 & 8.3 & 124.8 & 5.4 \\
\hline 3. $\mathrm{CO}$ & 30,000 & 10,120 & 2,666 & 6,812 & 2,407 \\
\hline 4. $\mathrm{O}_{3}$ & 200 & 185.5 & 85.8 & 101.0 & 66.3 \\
\hline \multirow{3}{*}{ Air pollutant } & \multicolumn{5}{|c|}{ 24-hour average concentration $\left(\mu \mathrm{g} / \mathrm{m}^{3}\right)$} \\
\hline & $\begin{array}{c}\text { QCVN } \\
05: 2013 /\end{array}$ & \multicolumn{4}{|c|}{ Simulation value } \\
\hline & BTNMT & $\begin{array}{c}\text { Dry } \\
\text { season } \\
\text { (max.) }\end{array}$ & $\begin{array}{c}\text { Dry } \\
\text { season } \\
\text { (min.) }\end{array}$ & $\begin{array}{l}\text { Rainy } \\
\text { season } \\
\text { (max.) }\end{array}$ & $\begin{array}{l}\text { Rainy } \\
\text { season } \\
\text { (min.) }\end{array}$ \\
\hline 1. $\mathrm{SO}_{2}$ & 125 & 16.5 & 7.2 & 12.9 & 7.1 \\
\hline 2. $\mathrm{NOx}$ & 100 & 75.3 & 5.9 & 60.1 & 4.1 \\
\hline 3. $\mathrm{CO}$ & - & - & - & - & - \\
\hline 4. $\mathrm{O}_{3}$ & - & - & - & - & - \\
\hline
\end{tabular}

- The grid cells with the highest 1-hour average concentration in Cai Rang, Ninh Kieu, and Binh Thuy districts:

1) Increase $\mathrm{CO}$ emission load by 1.96 times (corresponding to the highest 1-hour average $\mathrm{CO}$ concentrations were lower than the standard);

2) Increase NOx emission load by 0.51 times (corresponding to the 1-hour average of NOx concentrations were lower than the standard);

3) Increase $\mathrm{SO}_{2}$ emissions load by 12.4 times (corresponding to the 1-hour average of $\mathrm{SO}_{2}$ concentration were lower than the standard);

4) Do not change the emissions of NMVOC to observe the trend of $\mathrm{O}_{3}$ concentration when increasing NOx emissions.

Mar 01/2015, 8:00, C0 (kb), ppb

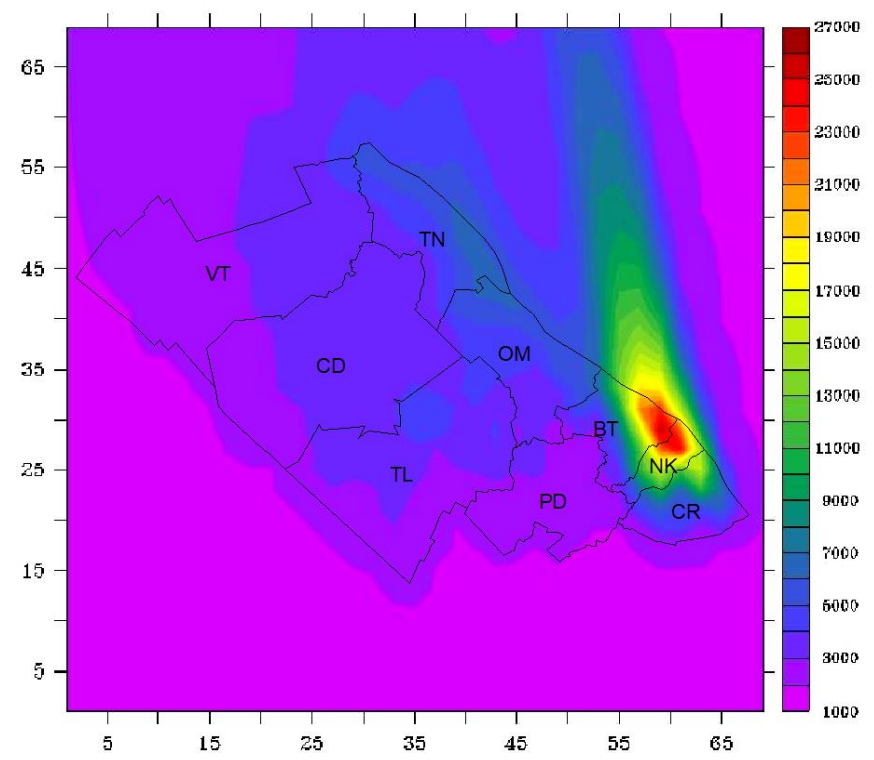


Mar 01/2015, 8:00, S02 (kb), ppb

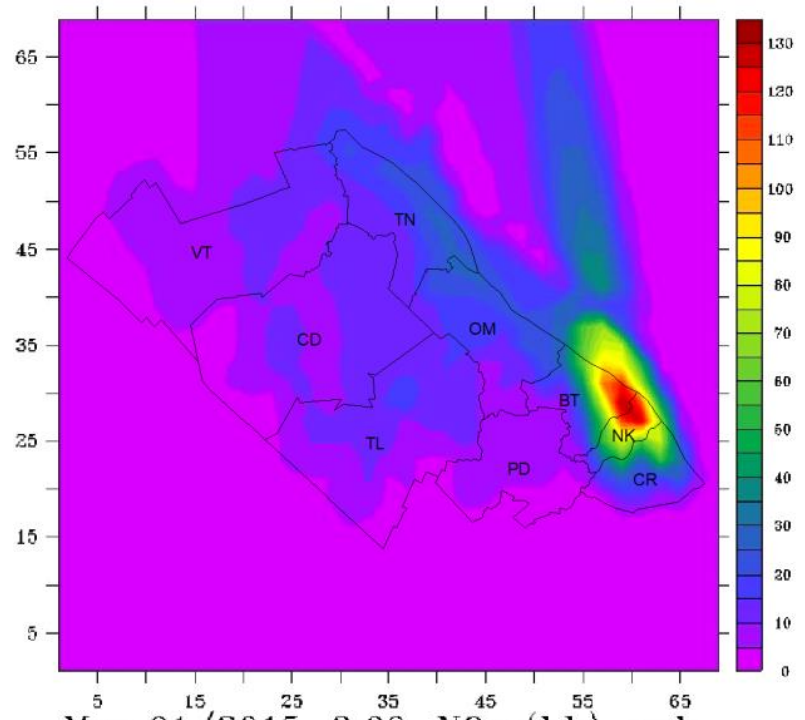

Mar $01^{15} / 2015,8: 00, \mathrm{NOx}^{25}(\mathrm{~kb}), \mathrm{ppb}^{65}$
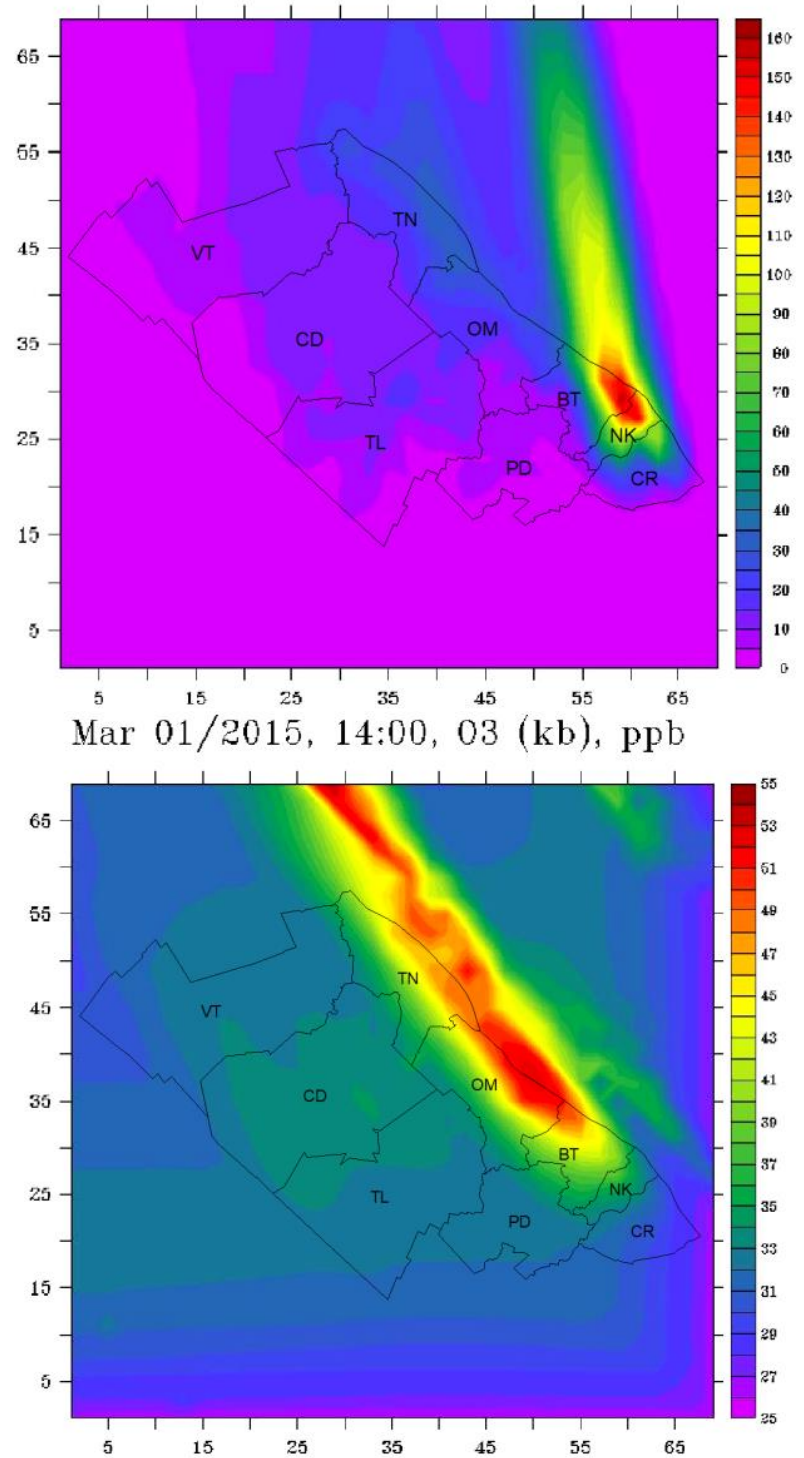

Fig. 9. The maximum 1-hour average of air pollutants concentration (CO, $\mathrm{SO}_{2}, \mathrm{NOx}, \mathrm{O}_{3}$ ) in dry season (in increasing emission scenarios).

- The grid cells with the lower levels of pollutants in Vinh Thanh, Co Do, Thoi Lai, and Phong Dien districts:

1) Increase $\mathrm{CO}$ emission load by 10.2 times (corresponding to the $\mathrm{CO}$ levels were lower than 11.2 times compared to the standard);

2) Increase NOx emission load by 23.2 times (since the 1hour average of NOx concentration were lower than QCVN 05: 201324.2 times);

3) Increase $\mathrm{SO}_{2}$ emission load by 46.5 times (corresponding to the $\mathrm{SO}_{2}$ concentrations were lower than 47.5 times compared to the standard);

4) Do not change NMVOC emission load to observe the variation of $\mathrm{O}_{3}$ concentration when increasing $\mathrm{NOx}$ emissions.
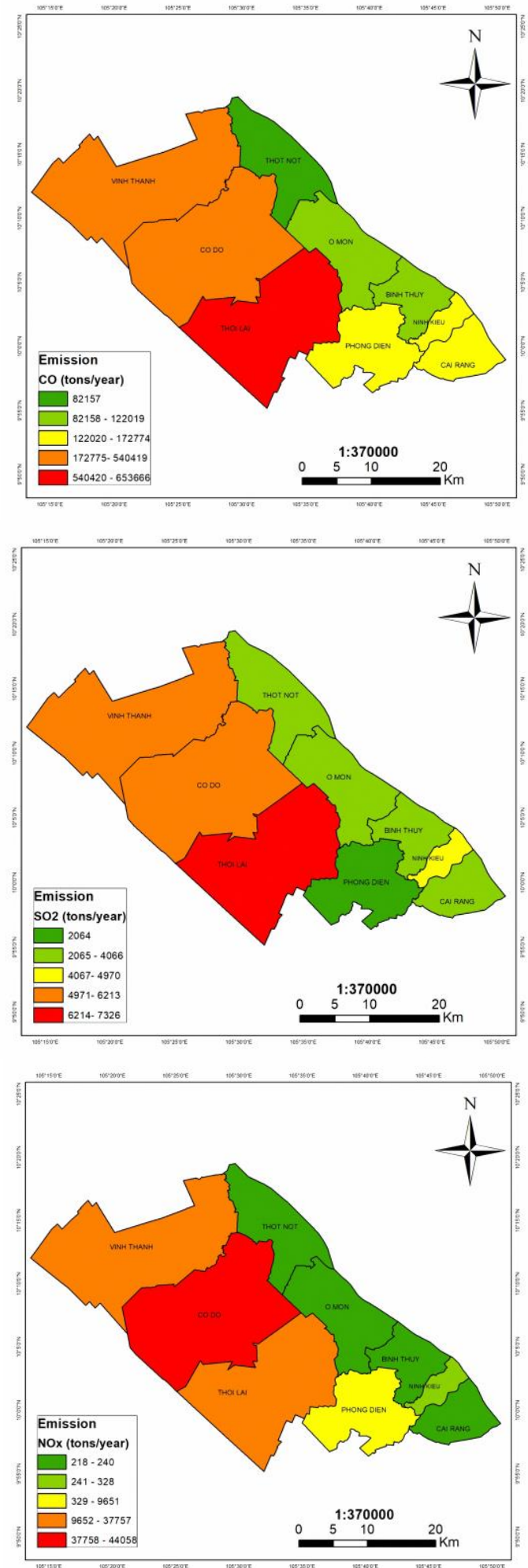

Fig. 10. Maps of the load-carrying capacity zoning of the atmospheric environment in Can Tho City (CO, $\left.\mathrm{SO}_{2}, \mathrm{NOx}\right)$. 
Simulating the emission scenarios in the dry season, when the peak of pollution was observed. The results showed that when increases $\mathrm{CO} 2.9$ times, $\mathrm{SO}_{2} 14.6$ times, and $\mathrm{NOx} 1.1$ times, the highest levels of pollutions had reached the standard value. Moreover, the ozone levels at this scenario had been reduced to $98 \mu \mathrm{g} / \mathrm{m}^{3}$, lower than the current status and the QCVN 05:2013, showing that $\mathrm{O}_{3}$ in this area witnessed the corresponding trend with NOx concentrations.

Concerning the area in the sub-urban area where the pollution levels were lower than the city center, continuing to simulations with the adjusted scenarios in the dry season. The highest levels of 1-hour average of pollutants met the standard when increasing the emissions of $\mathrm{CO}, \mathrm{SO}_{2}$ and $\mathrm{NOx}$ to 11.5 times; 47.5 times and 24.5 times, respectively. In this case, the observed ozone levels were $107.4 \mu \mathrm{g} / \mathrm{m}^{3}$, experiencing an increasing trend but still lower than QCVN 05:2013, witnessed the inverse trend with the NOx. A similar figure was perceived in the rain season.

Based on the results of air quality simulations using the adjusted scenarios in two seasons, the amount of pollutants that can be discharged into the air in Can Tho city was defined. The area that witnessed the high levels of air pollution such as Cai Rang (CR), Ninh Kieu (NK), Binh Thuy (BT), O Mon (OM) and Thot Not (TN) districts can receive more emissions with the amount of $\mathrm{CO}$ from 82,000 to 172,000 tons/year/district $\left(696-2,142\right.$ tons/year $\left./ \mathrm{km}^{2}\right)$; $\mathrm{SO}_{2}$ from 3,800 to 4,900 tons/year/district $(31-56$ tons/year $/ \mathrm{km}^{2}$ ); NOx from 217 to 328 tons/year/district (1.8 3.4 tons $/$ year $/ \mathrm{km}^{2}$ ). While the remaining districts (Vinh Thanh (VT), Co Do (CD), Thoi Lai (TL) and Phong Dien (PD) districts) where the pollution levels were low can receive a higher amount of pollutants such as 164,000 653,000 tons of $\mathrm{CO} /$ year/district $(1,308-2,555$ tons/year $\left./ \mathrm{km}^{2}\right) ; 5,500-7,300$ tons of $\mathrm{SO}_{2} /$ year/district $(17-$ 29 tons $/$ year $\left./ \mathrm{km}^{2}\right)$ and $31,000-44,000$ tons of NOx/year/district (77 - 147 tons/year $\left./ \mathrm{km}^{2}\right)$ (in Fig. 10). These results can be regarded by the City's government to improve the social-economic development plan in the coming years, especially, focusing on suburban districts of the city.

\section{CONCLUSIONS}

The study aimed to assess the loading-capacity of the atmosphere in Can Tho city using meteorology and air quality simulation models so that the scientists and the authorities can refer to propose the appropriate social-economic development plan at the local scale. The results showed that: the 1-hour and 24-hour average concentration of air pollutants $\left(\mathrm{SO}_{2}, \mathrm{NOx}, \mathrm{CO}\right.$, and $\left.\mathrm{O}_{3}\right)$ in both two seasons (dry and rainy seasons) were lower than the limited value of QCVN 05:2013/BTNMT. Which means, the atmospheric environment in Can Tho city is capable to receive more air emissions, and the amount of emissions the central districts can absorb were as $\mathrm{CO}$ from 82,000 to 172,000 tons/year/district $\left(696-2,142\right.$ tons/year/ $\left./ \mathrm{km}^{2}\right) ; \mathrm{SO}_{2}$ from 3,800 to 4,900 tons/year/district (31-56 tons/year $\left./ \mathrm{km}^{2}\right)$; NOx from 217 to 328 tons/year/district $(1.8-3.4$ tons $/$ year $/ \mathrm{km}^{2}$ ). For the remaining districts, the areas have the potential to receive $164,000-653,000$ tons of
CO/year/district $\left(1,308-2,555\right.$ tons $/$ year $\left./ \mathrm{km}^{2}\right), 5,500-$ 7,300 tons of $\mathrm{SO}_{2} /$ year/district $\left(17-29\right.$ tons/year $\left./ \mathrm{km}^{2}\right)$ and $31,000-44,000$ tons of NOx/year/district $(77-147$ tons $/$ year $/ \mathrm{km}^{2}$ ). However, the study had only calculated the amount of each pollutant that each district in Can Tho can receive, therefore in further research, it is needed to identify the sources of emissions that areas can put into operation to help the managers to have an overview to select the sector that can be developed in the future, integrated into the social-economic development plan to ensure the healthy environment while developing the economy.

\section{CONFLICT OF INTEREST}

The authors declare no conflict of interest.

\section{AUTHOR CONTRIBUTIONS}

Ho Minh Dung conducted the research and wrote the paper; $\mathrm{Vu}$ Hoang Ngoc Khue analyzed the data; all authors had approved the final version.

\section{REFERENCES}

[1] Decision No. 985a/QD-TTg in June $1^{\text {st }}$, “Approving the national action plan on air quality management to 2020 , vision to 2025," Prime Minister of Vietnam, 2016.

[2] D. R. Mandelker and T. A. Sherry, "Emission quota strategies as an air pollution control technique," Ecology Law Quarterly, vol. 5, no. 3, 1976.

[3] H. Fancy, "Good practice guide for assessing discharges to air from industry," Ministry for the Environment New Zealand, 2008.

[4] S. Thepanondh and N. Jitbantoung, "Assimilative capacity analysis of air pollutants over the Dawai industrial complex," International Journal of Environmental Science and Development, vol. 5, no. 2, pp. 161-164, 2014.

[5] A. Thawonkaew, S. Thepanondh, D. Sirithian, and L. Jinawa, "Assimilative capacity of air pollutants in an area of the largest petrochemical complex in Thailand," International Journal of GEOMATE, vol. 11, no. 23, pp. 2162-2169, 2016.

[6] S. Panda and S. M. S. Nagendra, "Assimilative capacity-based emission load management in a critically polluted industrial cluster," Journal of the Air \& Waste Management Association, vol. 67, no. 12, pp. 1353-1363, 2017.

[7] D. H. Xu, Y. Wang, and R. Zhu, "Atmospheric environmental capacity and urban atmospheric load in mainland China," Science China Earth Sciences, vol. 61, no. 1, pp. 33-46, 2018.

[8] MONRE, "National technical regulation on ambient air quality, QCVN 05:2013/BTNMT,” 2013.

[9] L. T. T. Thao and N. T. Q. Hung, "Building research and adjustment zoning to receiving industrial emission in Dong Nai province," Journal of Agricultural Science and Technology, vol. 2, pp. 66-76, 2016.

[10] D. H. Son, "Study of developing environmental planning for socio-economic development in the Hong river delta in the period 2001-2010," National Level of Science and Technology Program KC.08.02, 2003.

[11] N. T. T. Tram, "Study of evaluate the air quality zoning according to AQI index and propose solutions to improve air quality in Hanoi city," PhD thesis, National University of Civil Engineering, Vietnam, 2015.

[12] MONRE, "National technical regulation on industrial emission of inorganic substances and dusts, QCVN 19:2009/BTNMT," 2009.

[13] Decision No.22/2016/QD-UBND in April 6" "The regulation zoning of environment to receive wastewater and air emission in Binh Dinh province, period 2016 - 2020," The People's Committee of Binh Dinh province, 2016.

[14] Decision No. 35/2015/QD-UBND in October $19^{\text {th }}$, "The regulation zoning of environment to receive wastewater and industrial air emission in Dong Nai province," The People's Committee of Dong Nai Province, 2015.

[15] Decision No. 54/2017/QD-UBND in December 22 $2^{\text {th }}$ " "The regulation zoning of environment to receive wastewater and air emission in Vinh Phuc province," The People's Committee of Vinh Phuc Province, 2017.

[16] Decision No. 43/2011/QD-UBND in August 23 $3^{\text {th }}$, "The regulation zoning of environment to receive wastewater and air emission 
according to National Technical Regulation in Ba ria - Vung tau province," The People's Committee of Ba ria - Vung tau Province, 2011.

[17] Decision No. 1469/2011/QD-UBND in June $21^{\text {th }}$, "The regulation zoning of environment to receive wastewater and industrial air emission in Binh Phuoc province to 2020," The People's Committee of Binh Phuoc Province, 2011.

[18] H. Q. Bang, "Optimal methodology to generate road traffic emissions for air quality modeling: Application to Ho Chi Minh city," $\mathrm{PhD}$ thesis, EPFL, 2010

[19] H. Q. Bang, V. H. N. Khue, N. T. Tam, and K. Lasko, "Air emission inventory and air quality modeling for Can Tho city, Vietnam," Air Quality, Atmosphere \& Health, vol. 11, no. 1, pp. 35-47, 2018.

[20] A. Martilli, Y. Roulet, M. Junier, F. Kirchner, M. Rotach, and A. Clappier, "On the impact of urban surface exchange parameterisations on air quality simulations: the Athens case," Atmospheric Environment, vol. 37, pp. 4217-4231, 2003.

[21] A. Clappier, P. Perrochet, A. Martilli, F. Muller, and B. C. Krueger, "A new non-hydrostatic mesoscale model using a control volume finite element (CVFE) discretization technique," in Proc. the EUROTRAC Symposium '96. Computtational Mechanics Publications, Southampton, pp. 527-553, 1996.

Copyright $\odot 2021$ by the authors. This is an open access article distributed under the Creative Commons Attribution License which permits unrestricted use, distribution, and reproduction in any medium, provided the original work is properly cited (CC BY 4.0).

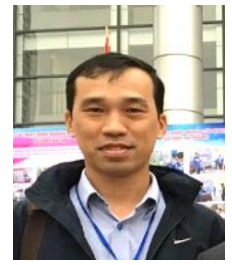

Ho Minh Dung is the head of Postgraduate Department - Institute for Environment and Resources - Vietnam National University, Ho Chi Minh city, Vietnam. He has the $\mathrm{PhD}$ degree in utilization and protection of environmental resources (2011). He has extensive experience with air quality management area (modeling, emission inventory, monitoring and treatment technology) and climate change. His current research involves air quality modeling, air pollution \& GHG emission inventory and climate change.

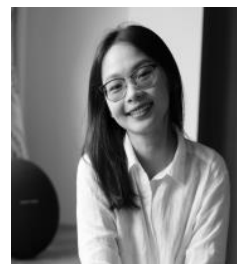

Vu Hoang Ngoc Khue has a master degree of environmental management. She has been worked in Centre of Air pollution and Climate change Research Center - Institute for Environment and Resources Vietnam National University, Ho Chi Minh city, Vietnam. She has experience with air quality modeling and emission inventory. Her current research involves air quality modeling, air emission inventory and climate change. 